\title{
Orvieto and Bagnoregio in the XIV century - a case study on city and countryside in Late Medieval Italy
}

\author{
Abstract \\ The aim of this article is to examine the interactions among main cities \\ and the rural communities subordinate to them in central Italy during Late \\ Middle Age. Premise of my work is the refusal of the assumption that \\ cities and towns interacted between them as a whole. I choose Orvieto \\ and its subordinate town of Bagnoregio in 1303 and 1304 as case study \\ to enlighten that parties and faction based in the city and in the town \\ interacted in ways that it is impossible to reduce to the dichotomy master- \\ servant: this links as a whole shaped the dialogue between the city and \\ its subordinates. \\ Keywords \\ Italy $\bullet$ Late Middle Age $\bullet$ cities $\bullet$ countryside $\bullet$ political history \\ ๑) University of Warsaw - Faculty of Geography and Regional Studies
}

Francesco Poggi

SAGAS. History, Archaeology, Geography, Art and Performing Arts, University of Florence, Italy e-mail: francesco.poggi@unifi.it

Received: 6 November 2018

Accepted: 18 March 2019
Introduction

In this essay I will analyse the relationships that existed at the beginning of the $14^{\text {th }}$ century between Orvieto, an Italian city in Umbria, and Bagnoregio, a town about twenty kilometres south of Orvieto. This article is part of the current historiographical debate, which I will shortly present in the first paragraph, about the interaction between the political actors in the cities and countries of central and northern Italy throughout the Late Middle Age. Studying the relationship between Orvieto and Bagnoregio allows us to observe these dynamics in a background more complex than the usual one shaped by the interaction between city and town. That was due to the particular status of Bagnoregio, which was a rural town from a demographical and economic point of view, but from the political standpoint it was considered a city, because it was a bishopric ${ }^{1}$, moreover, for its location was part of the Patrimonium Petri and juridically terra immediata subiecta to the Holy See.

City and Countryside in Late Medieval Italy, a short historiographical analysis

The making of the contado by cities and the relationships between them and the small towns and villages surrounding them are a traditional subject of the Italian historiography. From the $18^{\text {th }}$ century onward it's undisputed that the extent of political and juridical power exercised by the Italian city-states during the Middle Age over large rural areas was a unicum in all Europe (more about Italian historiography in 18th century in Peter 1996 and Imbruglia 2012). Since the beginning of the $20^{\text {th }}$ century, the analysis of the manner in which the cities built their

${ }^{1}$ More on the connection between bishopric and city status in Chittolini (1990) own contado became one of the prominent fields of research of the Italian Medieval Studies. In 1908-1909 Romolo Caggese published Classi e comuni rurali nel medio evo italiano, the first monograph dedicated to the contado building process. This book was a turning point in historiography, because for the first time an author pointed out the negative effects that the cities' domination had over towns and villages: Caggese underlined the vitality of social and political institutions of the Italian countryside and, at the same time, shed light on the burden that the cities put on them (Caggese 1908-1909). Throughout the first half of $20^{\text {th }}$ century, in the Italian academia there was a predominantly negative interpretation of contado, which was seen as an area exploited by cities. Giovanni de Vergottini in 1929 coined the expression "conquest of the contado [by the cities]", phrase which will be used for the next 50 years by Italian medievalists to summarize the violence exercised on the small towns by the cities in the course of their control of the countryside (De Vergottini 1929).

In 1934 was printed the first monograph which emphasized on the existence of different reactions from the country inhabitants to the cities expansion: in that year Johan Plesner had his thesis published. The Danish historian studied the emigration of the countrymen to Florence in the $13^{\text {th }}$ century and he concluded that more dynamic social groups took advantage of the Florentine expansion to strengthen their relations with the urban world, to have a better chance to accumulate wealth and social advancement (Plesner 1934). Since then, historians have developed a new interpretation of the relationships between cities and towns in central and northern Italy and begun to rethink not only the socio-economic perspective but also the 
political point of view. The late Fifties and early Sixties were especially fruitful for political analysis: in these years Philip James Jones started his lifelong studies of the Italian city-states, which gave a paramount contribution in the reconsideration of the role of cities in medieval Italy (Nobili 1980, Coleman 2010, Zorzi 2010), underlining the importance of extra-urban social and political factors ${ }^{2}$. Moreover, in 1961 Ernesto Sestan wrote a very important essay about the transition from Commune to Signoria, where he argued that in the $13^{\text {th }}$ and $14^{\text {th }}$ centuries, most of the urban ruling class, came from the contado and it ruled thanks to the resources it could mobilize from its castles and villages in the country (Sestan 1961, more on his works in Zorzi 2010, Zorzi 2012). Ernesto Sestan's works were crucial in raising a new generation of historians interested in studying the relationship between the cities and the countryside. Elio Conti - Sestan's assitant - Giovanni Cherubini, and Giuliano Pintoboth Sestan's students - were among those that developed a new line of research on these issues. These three historians, with the help of their students, were the first to choose to study the relationship between cities and countryside in central Italy from the point of view of the rural communities; at the same time, academics from Northern Italian universities analyzed the relations between cities and small towns in Lombardia, Piemonte and Veneto. Between the Sixties and the Eighties the social and economic history of the Italian countryside became one of the most important subjects in Italian historiography thanks to the coordinated works of dozens of scholars: throughout this twenty year period, an unmatched knowledge of the contado and its relationship with cities was achieved (Balestracci 2012, Cortonesi \& Passigli 2016). During the Nineties there was a decrease in the numbers of new studies on the subject and this offered an opportunity to revisit all the knowledge attained (Nobili 2013, Cortonesi \& Passigli 2016). Historians were no longer satisfied with an analysis that understands small towns and villages only as the victims of the aggressive expansionism perpetrated by the cities, neither did they accept an interpretation that denied the centrality of urban centres in Italy during the Middle Ages. In the late Nineties the first studies to aim their attention at the dynamism of the contado appeared: their purpose was to examine how social and political actors from small towns interacted with their counterparts in the cities. In recent years, historians are working to try and clarify how small communities reacted to actions from big urban centres and in which ways they could influence their behaviour.

\section{Orvieto and Bagnoregio at the beginning of $14^{\text {th }}$ century}

Orvieto and Bagnoregio are the subjects of my article and I will consider the years 1303 and 1304, because in that time Bagnoregio was the Orvieto government's main concern. Orvieto is a city halfway between Firenze and Roma, that reached seventeen-thousand inhabitants at the end of the ThirteenCentury and its contado extended over a large area in the south of Tuscany Waley 1952 it is the only monograph about Orvieto in the Middle Age; on the other hand, Bagnoregio is a small hill town twenty kilometres South of Orvieto, that had less than five thousand inhabitants. Bagnoregio was formally under the Church's authority, therefore Orvieto waited until the election of a friendly Pope to impose his influence on the small town so far there isn't any study on Bagnoregio in the Middle Age. In 1300, Pope Bonifacio VIII agreed to put Bagnoregio under Orvieto's protection, but he didn't clarify the limits of this "protection" SASO, Riformagioni, reg. 73 , cc. 90 r.-92 r., 04/12/1303. Thus began a complex set of relations among the political forces of the two cities,

\footnotetext{
${ }^{2}$ Philip James Jones wrote his first essay on an Italian city-state in 1952 and he summarised his peculiar interpretation of this subject in his chef-d'oeuvre The Italian City State from Commune to Signoria published in 1991 (Jones 1991).
}

because everybody knew that Orvieto ruled over Bagnoregio, but none perceived the guidelines that underlined this connection.

\section{Political relations between Orvieto and Bagnoregio}

On 16 February 1303, a delegation from Bagnoregio came to Orvieto, where it was immediately heard by the city council. Speaking before the councillors, the embassy complained that Bagnoregio had been attacked by a gang of Orvieto citizens. The envoys requested the conviction of all the people from Orvieto involved in the raid, both the assailants and their accomplices SASO, Riformagioni, reg. 73 , cc. 90 r.-92 r., 04/12/1303. In spite of the dissenting vote from part of the city council, the government of Orvieto fined every citizen heavily, including the city magistrates that helped the bandits, but this law really didn't say anything about the actual people from Orvieto that took part in the raiding party SASO, Riformagioni, reg. 73, cc. 90 r.-92 r., 04/12/1303. Some time after this assembly, there were riots in Orvieto that resulted in the demolition of the tower of the Lupicini family, an aristocratic lineage that supported the gang that raided Bagnoregio (ed. Fumi 1902). This matter was debated again in the city council in December, when the assembly annulled the sentence of the city court on Neri di Romano, the leader of the gang that assaulted Bagnoregio SASO, Riformagioni, reg. 73, cc. 90 r.-92 r., 04/12/1303.

At the beginning of December, just before the amnesty given to Neri, Bagnoregio was attacked once again by rebels and bandits. This time it was a noble citizen of Orvieto, Ugolino Monaldeschi, member of the most powerful and richest family in Orvieto, who came to speak before the city council. The nobleman demanded that the city government concede him the right to reprisal against Bagnoregio, because, as Ugolino told the council, the inhabitants of Bagnoregio had cooperated with the rebels that attacked and expelled him from the town where he was serving as the elected podestà SASO, Riformagioni, reg. 73, cc. 90 r. -92 r., 04/12/1303. This fact shows us that Orvieto exercised its authority over Bagnoregio through the election of powerful people to the governor's office and that these elections were arranged by Bagnoregio's inhabitants more on podestà in Maire Vigueur 2000. The implication is that part of the town population fought against Orvieto's domination of Bagnoregio, but that part of the population also supported this situation: this fact indicates that there was a political group allied with the Orvieto government in Bagnoregio. Considering this, it is impossible to interpret the attack on Bagnoregio in early 1303 only as a raid for plunder, because it was also an aggression by citizen from Orvieto on a town ruled by a faction allied to their own city. Apparently, the political institutions of Orvieto condoned this assault: as previously stated, the city council refused to clearly condemn the attackers and repeal the sentence given to their leader by the city court: one councillor even stated that the inquiry was a reaction to the pressure from Bagnoregio inhabitants, suggesting that Orvieto's citizens didn't support the judge's ruling.

The relationship between Orvieto e Bagnoregio put the struggle for Maremma and the Papal authority in their political and territorial context.

To analyse the political situation in Orvieto in these years, it is necessary to understand why in Orvieto there was a faction ready to attack their city's allies. At the end of the $13^{\text {th }}$ century in Orvieto there were two conflicting coalitions, one that wanted to use the city resources to annex a region in south of Tuscany called Maremma, west of Orvieto, while the second preferred to strengthen the city dominion over the road between Florence and Rome, to the north-east of the city. Starting in 1296, the government of Orvieto backed the project to conquer Maremma, while the other forces were in opposition. In that year many members of the Orvieto ruling class were excommunicated by Pope Bonifacio 


\section{CENTRES D'INTERÊT ET IMPLANTATION DES ORDRES MENDIANTS A LA FIN DU XIII' SIÈCLE \\ Plan $n^{\circ} 2$}

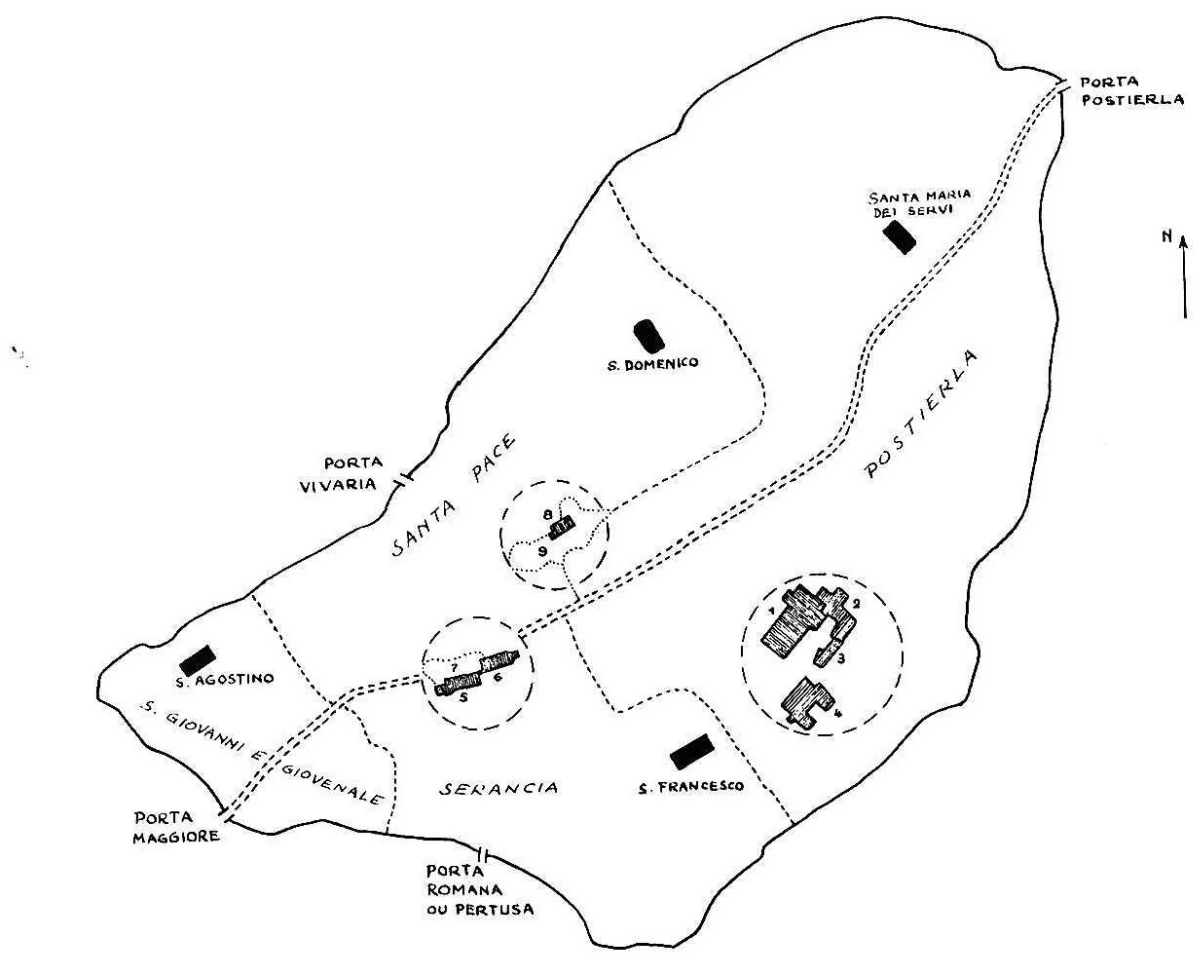

Echelle 운

\author{
LEGENDE \\ 1. Dôme \\ 2. Palais de l'évêque \\ 3. Palais du pape \\ 4. Hôpital Santa Maria della Stella \\ 5. Palazzo del Comune \\ 6. Eglise $S$. Andrea \\ 7. Piazza del Comune \\ 8. Palazzo del Popolo \\ 9. Piazza del Popolo
}

sニニン:ニ Via Mercanzia

...... Limites approximatives des quartiers

Figure 1. Orvieto districts. Source: Carpentier 1986. Orvieto at the end of the 13th century, its four districts, places of interest and mendicant churches

VIII (eds Digard, G. \& Faucin M. \& Thomas A. 1881), and the faction that backed the project to conquer Maremma took power in the city. From this perspective, the attack on Bagnoregio in 1303, when the subjugation of Maremma was nearly accomplished, was an attempt to put pressure on the Orvieto government and hinder its strategy in the south of Tuscany. The involvement of Lupicini family in the assault of Bagnoregio corroborates this: this was one of the richest and most powerful noble families in Orvieto during the $13^{\text {th }}$ century, but it had lost many properties and most of its political influence after 1269, when most of its members where condemned for heresy and its goods were sold at auction (Henderson 1990). The families that benefitted most from the fall of the Lupicini were those ruling Orvieto at the end of the $13^{\text {th }}$ century and that supported the annexation of Maremma. In spite of their setbacks, at the beginning of the XIV century, Lupicini was still a rich family that would gladly support anyone that attacked their old rivals (Pardi, 1896). Of course, loot was one of the main goals of the raid on Bagnoregio, but it was not the only one; to cause a lot of problems for the forces that ruled Orvieto was another aim for sure. The nomination of Ugolino Monaldeschi as podestà right after the attack is proof of the existing link between a faction in Bagnoregio and the political forces that ruled Orvieto. The Monaldeschi family supported the Orvieto government and its alliance with Pope Boniface VIII more about this family in Riccetti 1995. The decision of Bagnoregio inhabitants to elect a member of this family as governor was instrumental in reaffirming the existing alliance between factions in Orvieto and Bagnoregio and a way to overcome the political consequences of the attack. The analysis of the councillors that spoke in behalf of Bagnoregio confirm that the Monaldeschi were a link between the Orvieto 


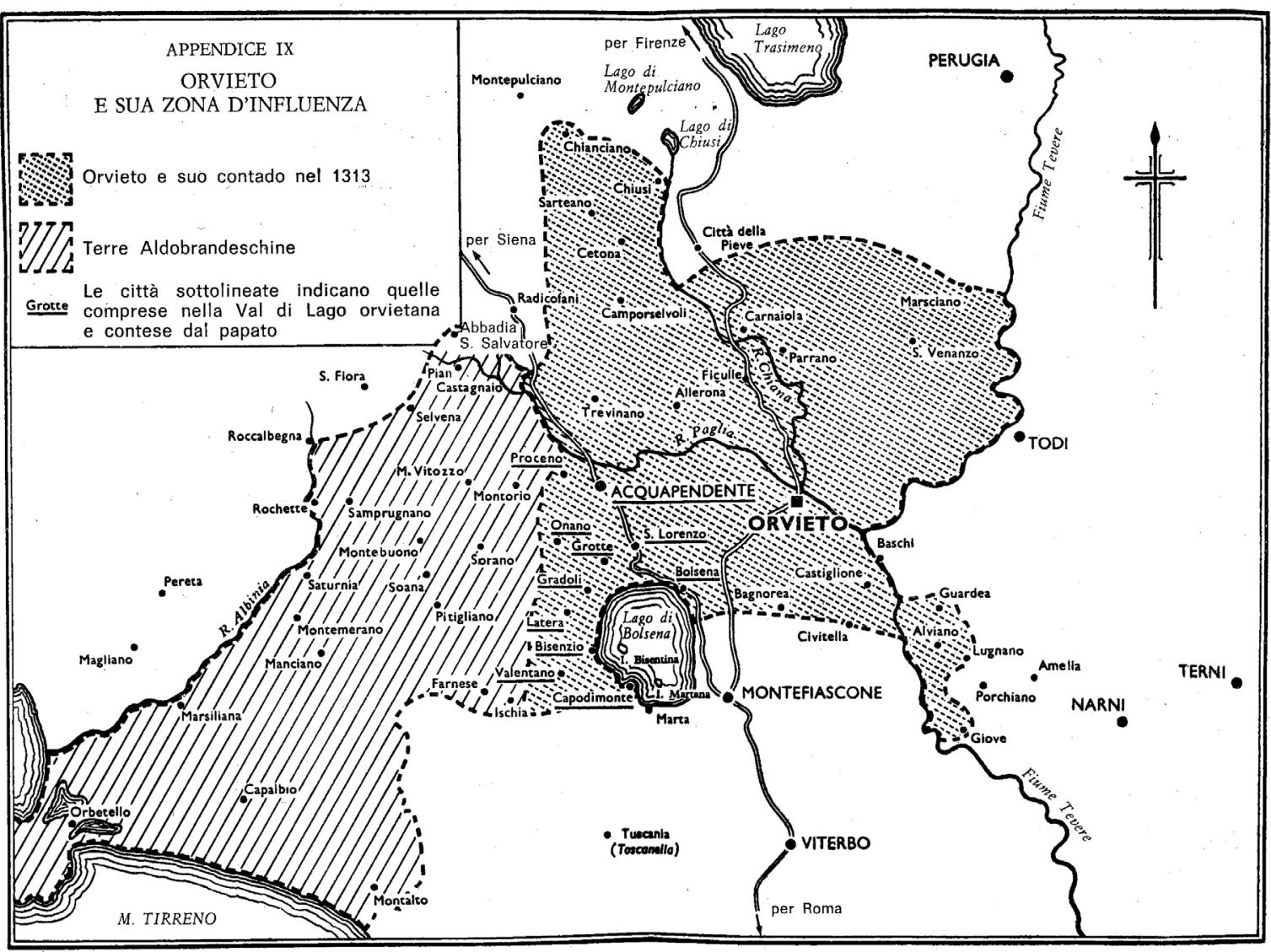

Figure 2. Orvieto Sphere of Influence. Source: Waley 1952. Dotted area maps Orvieto and its contado in 1313, the diagonal lines identify Maremma region, cities underlined where claimed by Orvieto and the Pope

regime and the Bagnoregio ruling class: most of the spokesmen were tied to the Monaldeschi by bond of alliance or by shared business interests ${ }^{3}$.

However, in Bagnoregio there were also political factions that rejected the influence of Orvieto over their town. From their point of view, the February attack meant that there were forces in Orvieto that were willing to do anything to hinder the government of their city: this was the first opportunity in three years to overturn the ascendancy of Orvieto over Bagnoregio and to challenge the regime close to Orvieto. This faction made an agreement with marauders camped near the town: the outlaws attacked Ugolino and his men and instituted a new government which was hostile to Orvieto. The reactions of the political forces of the dominante to the attack was quite surprising: when Ugolino Monaldeschi requested the support of his government against Bagnoregio, 2 out of 5 of the city councillors opposed his petition and, over the following months, half of the council members took the side of the new regime in Bagnoregio SASO, Riformagioni, reg. 73, cc. 154 v. - 158 r., 10/06/1304. As further proof of the fact that this support was motivated by the opposition to Orvieto's government and the Monaldeschi family, the councillors ceased their support of Bagnoregio in late 1304, when Manno Monaldeschi, a cousin of Ugolino, conquered the town and ousted the new regime (ed. Fumi 1902).

${ }^{3}$ Tudino di Buongiovanni, Odduccio di Andreotto - the two spokesmen that followed up this matter in the Orvieto city council - (SASO, Riformagioni, reg 71, c. 157 r., 23/02/1301; SASO, Riformagioni, reg. 73, cc. 68 r. - 69 v., 30/09/1303) and the Monaldeschi family (Carpentier 1986, SASO, Riformagioni, reg. 72, c. 220 v., $26 / 09 / 1302$ ) were all heavily involved in animal husbandry and the conquest of Maremma

\section{Conclusions ${ }^{4}$}

The two battles that took place in Bagnoregio in 1303 and their political follow up in Orvieto, allow us to observe how complex the relations between political actors of the dominant city and the ones based in towns of its contado could be. In February, political forces from Orvieto raided Bagnoregio. They chose to attack the small town as a way to indirectly hamper their government effort to subjugate the Maremma. The ruling faction of Bagnoregio didn't react like a community deferential to its master: it didn't beg for justice or compensation, instead it sent its most noble men as spokesmen to Orvieto, where they negotiated with the councilors as equals. The representative of Bagnoregio convinced the city officials to start an inquiry into the attack and subsequently the investigation lead to the condemnation of the attackers' leader. Many citizens of Orvieto didn't approve that a town under their influence dictated its will to them, and they demonstrated it by annulling the sentence given to the bandit, but they couldn't ignore the formal request made by the small town. First of all, the Orvieto government needed at least the support of one political faction in Bagnoregio to exercise its ascendency over the town, therefore it had to ensure them fair treatment from

${ }^{4}$ The case study presented here has some interesting points in common with the way Avignon forced its power on the rural communities around it: in doing so, the French city relied on the support of the Count of Toulouse, who was one of the legitimates lords of that region. But he needed the help of the city during the hard times of the Albigesian Crusade (1202-1229) (Balossino 2012). We could also make a meaningful connection comparing the relationships developed by the Orvieto councils with the countryside, and the politics implemented by the Milan government at the beginning of the $14^{\text {th }}$ century, which chose to strengthen its institutions in order to deal with political actors based in the countryside (Grillo 2003). 
its institutions. Secondly, Orvieto's rule over Bagnoregio was based on the Pope's decision to grant such authority and this was backed up by the fact that the pontiff was by right the legitimate lord of Bagnoregio; for this reason Orvieto had to respect the norms of relations between cities to maintain the validity of its authority.

In November 1303 a political group in Bagnoregio planned and perpetrated an attack on the governor from Orvieto and his men. This event allows us to observe that factions from a small town could interact in several ways with the government of their dominante. Despite the February raid, political groups in Bagnoregio tried to strengthen the liaison with Orvieto by choosing a member of the most powerful family in the city as governor. Concurrently, a faction in Bagnoregio took advantage of the organised opposition in Orvieto to banish the Monaldeschi and take power. It is highly probable that there was an understanding between the opposition in Orvieto and the rebels in Bagnoregio, as there was no official reaction after the ousting and half of Orvieto city council maintained good relations with the new regime in Bagnoregio.

\section{References}

\section{Manuscript Sources}

Sezione di Archivio di Stato di Orvieto (SASO), Archivio di Stato di Terni [State Archive of Terni, section of Orvieto], Riformagioni, 71 (1298-1301), 72 (1300-1304), 73 (1300-1304).

\section{Secondary Sources}

Balestracci, D 2012 'Giovanni Cherubini e la storia delle campagne. Un tema démodé?' ['Giovanni Cherubini and the rural history. A topic out-of-date?'], in Uomini, paesaggi, storie: studi di storia medievale per Giovanni Cherubini, eds. D Balestracci \& A Barlucchi \& F Franceschi \& P Nanni \& G Piccinni \& A Zorzi, SeB, Siena, pp. 1115-1129.

Balossino, S 2012 'Un territorio conteso: l'espansione del comune di Avignone nelle aree extracittadine (prima metà del secolo XIII)' ['A contested territory: the expansion of Avignone commune in the countryside (first half of the $13^{\text {th }}$ century)' ], Mélanges de l'École française de Rome - Moyen Âge, vol. 123, n. 2, pp. 397-416.

Barlucchi, A 1997, Il contado senese all'epoca dei Nove. Asciano e il suo territorio tra Due e Trecento [The senese contado in the age of Nove. Asciano and its district between 12th and 14th century], Leo S. Olschki, Firenze.

Barlucchi, A 2018, 'Città e territorio a Cortona nel Duecento' ['City and countryside in Cortona during the $13^{\text {th }}$ century'], in Frate Elia e Cortona. Società e religione nel XIII secolo, ed A. di Marcantonio, CISAM, Spoleto, pp. 59-88.

Caggese, R 1908-1909, Classi e comuni rurali nel medio evo italiano [Classes and rural communes in the Italian Middle Age], Galileiana, Firenze.

Carpentier, E 1986, Orvieto à la fin du XIII siècle. Ville et campagne dans le cadastre de 1292 [Orvieto at the end of the Thirteen century. City and countryside studied in the cadastre of the 1292], Éditions du CNRS, Paris.

Cherubini, G 1974, Signori, contadini, borghesi. Ricerche sulla società italiana nel medioevo [Nobles, farmers, middle class men. Studies on the Italian medieval society] La nuova Italia, Firenze.

Cherubini, G 1985, L'Italia rurale nel basso Medioevo [Rural Italy during Late Middle Age], Laterza, Roma-Bari.
The confirmation of Orvieto's influence over Bagnoregio by the Pope put the small town under the city's rule, but it also made possible for the political forces of the two urban settlements to interact with each other. Bagnoregio elected governors from Orvieto, but the power of these officials was balanced by the actions of the inhabitants, which could even collaborate with factions in Orvieto to undermine their authority. At the same time, neither the government nor the opposition in Orvieto considered the people from Bagnoregio simply as their vassals: on the contrary, they regarded them as political actors with whom to develop complex factional relationships. To conclude, Bagnoregio is an example of a contado town that was far from being just an area to be exploited by Orvieto, it was actually a counterpart for its institution and political forces.
Cherubini, G 1991; Scritti toscani: l'urbanesimo medievale e la mezzadria [Tuscan writers: medieval urbanization and the mezzadria], Salimbeni, Firenze.

Chiappa Mauri, L (ed.) 2003, Contado e città in dialogo. Comuni urbani e comunità rurali nella Lombardia medievale [Contado and city in dialogue. Communes and rural communities in medieval Lombardy], Cisalpino, Milano.

Chittolini, G 1979, La formazione dello stato regionale e le istituzioni del contado, secoli XIV e XVI [The rise of the Italian regional states and the contado institutions, 14th and 16 th century], Einaudi, Torino.

Chittolini, G 1990, '"Quasi città". Borghi e terre in area lombarda nel tardo medioevo' ['Almost-cities". Town and villages in Lombardy in late Middle Age'], in Società storia, vol. 13, n. 47, pp. 3-26.

Coleman, E 2010, Jones, Philip James (1921-2006), historian. Oxford Dictionary of National Biography. Available from: <https://www.oxforddnb.com/ view/10.1093/ref:odnb/9780198614128.001.0001/odnb9780198614128-e-97198 > [09 January 2019].

Comba, R 1983, Metamorfosi di un paesaggio rurale. Uomini e luoghi del Piemonte sud-occidentale dal $X$ al XVI secolo [Metamorphosis of a country landscape. Men and places in south-western Piedmont between the 10th and the 16th century], CELID, Torino.

Conti, E 1965, La formazione della struttura agraria moderna nel contado fiorentino [The creation of the modern agrarian structure in the Florentine contado], Istituto Storico Italiano per il Medioevo, Roma.

Cortonesi A, Passigli S 2016, Agricoltura e allevamento nell'Italia medievale. Contributo storiografico, 1950-2010 [Agriculture and breeding in medieval Italy. Historiographic essay, 19502010], Firenze University Press, Firenze.

De Vergottini, G 1929, 'Origini e sviluppo storico della comitatitanza' ['Origins and historical development of comitatitanza'], Studi Senesi, vol. 43, pp. 347-481.

Digard, G \& Faucin M \& Thomas A (eds.) 1881, Les Registres de Boniface VIII. Recueil des Bulles de ce Pape. Publièes ou Analysèes d'après les Manuscrits originaux des Archives du Vatican [Boniface 8th registers. Collection of bulls form this 
Pope. Published and Analysed from the original manuscripts in the Vatican Archives], Bibliotèque des Écoles Françaises d'Athènes \& de Rome, Paris.

Francesconi, G 2011, 'Scrivere il contado. I linguaggi della costruzione territoriale cittadina nell'Italia centrale' ['Writing the contado. The language for the construction of the contado in central Italy'], Mélanges de l'École française de Rome - Moyen Âge, vol. 123, n. 2, pp. 499-529.

Fumi, L (ed.) 1902, Ephemerides Urbevetanae dal Codice Vaticano Urbinate del 1745 [Ephemerides Urbevetanae from the 1745 Vatican Codex Urbinate], S. Lapi, Firenze (Città di Castello).

Grillo, P 2003, 'Comuni urbani e poteri locali nel governo del territorio in Lombardia (XII-inizi XIV secolo)' [Urban communes and rural authority governing the countryside in Lombardy (12 $12^{\text {th }}$-beginning $14^{\text {th }}$ century)], in Contado e città in dialogo. Comuni urbani e comunità rurali nella Lombardia medievale, Cisalpino, Milano, pp. 41-82.

Grillo, P 2006, 'Statuti cittadini e governo del territorio nell'Italia nordoccidentale (XIII-inizi XIV secolo)' ['Cities' statutes and ruling the countryside in north-western Italy $\left(12^{\text {th }}\right.$-beginning $14^{\text {th }}$ century)'], in Le comunità rurali e i loro statuti, secoli XII-XV: Viterbo, 30 maggio-1. giugno 2002 : VIII Convegno del Comitato italiano per gli studi e le edizioni delle fonti normative, ed. A. Cortonesi \& F. Viola, Gangemi, Roma, pp. 57-75.

Handerson, M J. 1990, Piety and Heresy in Medieval Orvieto. The Religious Life of the Laity, c. 1150-1350., Ph. D. thesis, University of Edinburgh.

Imbruglia, G 2012, 'Muratori, Ludovico Antonio', Dizionario Biografico degli Italiani, vol. 77. Available from: <http://www.treccani. it/enciclopedia/ludovico-antonio-muratori_\%28DizionarioBiografico\%29/ >. [18 January 2019].

Jones, P.J. 1991, The Italian City State from Commune to Signoria, Oxford University Press, Oxford.

Nobili, P.G. 2013, 'I contadi organizzati. Amministrazione e territorialità dei "comuni rurali" in quattro distretti lombardi (1210-1250 circa)' ['Organized contadi. "Rural communes" administration and territory in four Lombard districts (12101250 circa)'], Reti Medievali Rivista, vol. 14, n. 1, pp. 81-130.

Maire Vigueur, J.-C. (ed.) 2000, I podestà nell'Italia comunale [The podestà in Italian City-States], École Française de Rome, Roma.

Pardi, G 1896, 'Il catasto di Orvieto dell'anno 1292' ['The 1292 cadastre of Orvieto' ], Bollettino della Società Umbra di Storia Patria, vol. 2, pp. 225-320.

Peter, B 1996, The Cambridge History of Italian Literature, Cambridge University Press, Cambridge.

Pinto, G 1978, Il libro del Biadaiolo. Carestie e annona a Firenze dalla metà del '200 al 1348 [The book of the Biadaiolo. Famines and food politics in Florence form half of Thirteen century to 1348], Leo S. Olschki, Firenze.

Pinto, G 1982, La Toscana nel Tardo Medioevo. Ambiente, economia rurale, società [Late medieval Tuscany. Environment, rural economy, society], Sansoni, Firenze.

Pinto, G \& Poni C. \& Tucci U. (eds.) 2002, Storia dell'agricoltura in Italia II. II Medioevo e l'Età Moderna [History of the agriculture in Italy 2. The Middle Age and the Early Modern], Polistampa, Firenze.

Pirillo, P 2001, Costruzione di un contado. I fiorentini e il loro territorio nel basso Medioevo, Le Lettere, Firenze.
Plesner, J 1934, L'Emigration de la Campagne à la ville libre de Florence au XIIle siècle [The emigration from the countryside to the free city of Florence during the Thirteen century], Gyldendalske Bochandel-Nordisk, København.

Riccetti, L 1995, 'Monaldeschi, Filippeschi, comune ad Orvieto nel medioevo' ['Monaldeschi, Filippeschi, commune and Orvieto in the Middle Age'] in I Monaldeschi nella storia della Tuscia. Atti della giornata di studio, ed. Quattrini A., Bolsena, pp. 5-17.

Sestan, E 1961, 'Le origini delle signorie cittadine: un problema storico esaurito?' [The origins of urban signorie: an outdated historical topic?], in Bullettino dell'Istituto Storico Italiano per il Medioevo, vol. 73, pp. 41-70.

Varanini, G.M. 1980, II distretto veronese nel Quattrocento. Vicariati del Comune di Verona e vicariati privati [The Verona district in 15th century. Verona commune vicariate and private vicariate], Fiorini, Verona.

Waley, D.P. 1952, Mediaeval Orvieto: The Political History of an Italian City-State 1157-1334, Cambridge University Press, Cambridge.

Zorzi, A 2010, Le signorie cittadine in Italia (secoli XIII-XV) [Urban signorie in Italy (13th-15th century)], Bruno Mondadori, Milano.

Zorzi, A 2012, 'Un problema storico non esaurito: le signorie cittadine. Rileggendo Ernesto Sestan' ['Not an outdate historical topic: the urban signorie. Rereading Ernesto Sestan'], in Uomini, paesaggi, storie: studi di storia medievale per Giovanni Cherubini, eds. D Balestracci \& A Barlucchi \& F Franceschi \& P Nanni \& G Piccinni \& A Zorzi, SeB, Siena, pp. 1247-1264. 